$\frac{p}{9}$ 


\section{A questão nacional: a modernização}

\section{RATMUNDO FAORO}

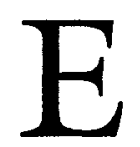

m 1915, num ensaio que faria época, acerca da Alemanha Imperial, Veblen celebrou, na corrida, entre as naçóes, pelo desenvolvimento, as vantagens do atraso (the advantages of backwpardness). Inaugurava-se, com o paradoxo, um debate, que evocava um retalho de história do mundo, que até então permanecera na sombra, reservada a área luminosa às naçốes desenvolvidas. $O$ paradoxo não acaba aí: se o país que, no começo da corrida, se situa nas últimas filas, e, por isso, privilegia a sua trajetória, há, correlatamente, o castigo da liderança (The penalty of taking the lead). Entre as duas marcas - a que assinala $o$ país atrasado e a que indica o paradigma - situa-se o fenômeno que se chama a modernizaf̧ão - que outrora, guardadas as diferenças de tempo e de estrutura histórica, constituiria a europeização ou a ocidentalizaçáo. Duas naçóes, na primeira metade do século XX, depois de uma arrancada que as destacou no mundo, eram os exemplares da modernização: a Alemanha e o Japão. Os dois países teriam, ao se industrializarem, assimilado e incorporado ao seu desenvolvimento a tecnologia dos países paradigmaticamente adiantados, queimando etapas, sem pagar, em termos sociais e econômicos, o alto e aflitivo preço que os ingleses pagaram pela conquista da liderança (The portable Veblen. Pinguim Books, 1976). Não previra Veblen, embalado pela imagem de retórica - as vantagens do atraso -, um oxímoro que vale tanto como o " contentamento descontente" de Camões, da eventual patologia, congenial às modernizaçóes. $O$ que ele supunha ser uma franja incidental se revelaria, nos meados do século, uma enfermidade, só extirpável com o desaparecimento da própria modernizaçáo, como fenômeno aderido ao país em desenvolvimento.

Haveria, dessa maneira, no país atrasado, um tempo célere, que encurtaria a distância para alcançar a primeira fila. Um tour de force $o$ distinguiria do paradigma. No ponto de chegada, a diferença deixaria de existir, situados os modernizadores, também eles, entre os líderes. $O$ caminho a percorrer, pelo país atrasado, năo seria, dessa sorte, o mesmo do país desenvolvido. $O$ prefácio de $O$ capital, de 1867 , na parte que afirma que "O país industrialmente mais desenvolvido (Das industrielle 
entwikeltere Land) mostra ao país menos desenvolvido táo-somente a imagem do próprio futuro (das Bild der eignen Zukunft)", conteria meia verdade (Alexander Gerschenkron. Economic bacwardness in historical perspective. Cambridge, 1976, p.6). E ainda com uma diferença: a realidade no país atrasado no vôo pelo desenvolvimento seria, socialmente, muito pior do que a líder, somando as misérias modernas às misérias herdadas (Karl Marx. Das Kapital. MEW, 23, p.12; O capital. São Paulo, 1983 , p.12). Uma nação pode aprender com as outras e, depois que descobrir a pista da lei natural do seu desenvolvimento, náo pode saltar etapas por decreto, embora esteja no seu poder minorar e abreviar as leis do parto - acrescentava o esquecido prefácio. $O$ desenvolvimento começa com a descoberta desta pista da lei do desenvolvimento. Antes que ela se revele, como uma iluminação valorativa, a sociedade atrasada dorme, sem as tensóes que aí começam. Se o desenvolvimento é mera extensão de uma fonte desenvolvida, como nas colônias gregas e, possivelmente, nos Estados Unidos com relação à Inglaterra, não se pode falar em modernização.

O confronto das duas teses define, com clareza, o perfil da chamada modernizaf̧âuo. Pode-se, se a modernização é de fato o que Veblen supôs que ela fosse, encadear uma em outra, entre as naçóes, num regresso ad infinitum. A Alemanha teria se modernizado de acordo com o modelo inglês, a Inglaterra, em sequiência ao padrão europeu ocidental. Assim seria, se o desenvolvimento se tivesse operado por esse processo. Mas se, afora a modernizafão, há o caminho da modernidade, além da atraçáo do antecedente, existe algo mais. Há a descoberta da pista da lei natural do desenvolvimento. Sem a impureza positivista, que está na idéia de lei, existe aqui um eco hegeliano - o desenvolvimento como devenir, como atualização - que nega a hipótese do encadeamento regressivo de modernizações e da própria modernização como via de desenvolvimento. Este é um tema a que se voltará. Diga-se, por enquanto, que a modernidade compromete, no seu processo, toda a sociedade, ampliando o raio de expansão de todas as classes, revitalizando e removendo seus papéis sociais, enquanto que a modernizą̧ão, pelo seu toque voluntário, se não voluntarista, chega à sociedade por meio de um grupo condutor, que, privilegiando-se, privilegia os setores dominantes. Na modernização náo se segue o trilho da "lei natural", mas se procura moldar, sobre o país, pela ideologia ou pela coação, uma certa política de mudança. Traduz um esquema político para uma ação, fundamentalmente política, mas economicamente orientada, para usar a língua de Weber. A ação 
social, que dela decorre, não parte da economia, como expressão da sociedade civil. Na modernidade, a elite, o estamento, as classes - dizemos, para simplificar, as classes dirigentes - coordenam e organizam um movimento. Náo o dirigem, conduzem ou promovem, como na modernizaf̧ão. A modernizaf̧ão, quer se chame ocidentalização, europeização, industrialização, revolução passiva, via prussiana, revolução do alto, revolução de dentro - ela é uma só, com um vulto histórico, com muitas máscaras, tantas quantas as das diferentes situaçóes históricas. Talvez se possa dizer, ainda, que a modernizaç 0 , ao contrário da modernidade, cinde a ideologia da sociedade, inspirando-se mais na primeira do que na segunda.

Fundamentalmente, a modernização é um traço de linhas duplas: a linha do paradigma e o risco do país modernizável. Quando ela, a modernização, se instaura, como ação voluntária, quem a dirige é um grupo ou classe dirigente - com muitos nomes e de muitas naturezas que, na verdade, não reflete passivamente a sociedade sobre a qual atua. Tal grupo, para mudar o que não vai, ao seu juízo, bem, começa por dissentir da classe dirigente tradicional. $O$ desvio, entretanto, não altera a pirâmide social, nem os valores dominantes. Um exemplo, para antecipar, será a projetada e frustrada reforma que se quis derivar da recepção do Positivismo comtista, no século passado. Militares, engenheiros e médicos, uma elite que não conseguia dar as cartas no estamento imperial - depois chamado a pedantocracia legista - , formam, não uma nova sociedade, mas um novo estamento, para que ocupe o lugar do antigo. $\hat{E}$ claro que de tal ascensão insegura só resultará uma mudança espasmódica, limitada, incapaz de imantar toda a sociedade. A pauta dupla, que o emoldura, com duas forças dentro de um projeto, não pode se dissolver, porque a isso se opóe a necessidade da elite dissidente de controlar, medir e regular o âmbito da mudança, sempre circunscrita aos valores que não pode alterar. Deste molde as modernizaçóes brasileiras nunca saíram, prisioneiras de uma estrutura econômica, intangível à sua ação.

As modernizações, como modelo de desenvolvimento, assumem um perfil definido já no século XVIII. A Rússia de Pedro, o Grande (1682-1725), se propôs, no desesperado atraso econômico em que se encontrava, entrar em disputa com países mais adiantados, o que o obrigou a procurar alcançá-los, a ferro e fogo. Igualmente, o descom- 
passo de economias, nas quais uma sugava - real ou presumidamente - a outra, levou Pombal (1775-1777), "reunindo coraçôes e espíritos", como dizia, a procurar estancar a sangria. Era necessário reformar a monarquia e a economia: "A monarquia estava agonizando. Os ingleses tinham peado esta nação $\mathrm{e}$ a tinham debaixo de sua pendência: eles a haviam insensivelmente conquistado, sem ter provado dos inconvenientes das conquistas" (J. Carvalho e Melo, Marquês de Pombal. Cartas e outras obras seletas do Marquez de Pombal. Lisboa, 1881, 5 ed., v. 2, p.103). As reformas partiam de uma plataforma intelectual, ideológica: antes de tudo, recuperar o pensamento científico, tolhido pela Escolástica. Uma economia calcada sobre a burguesia comercial, cevada de estímulos e privilégios, viria a ser, no futuro, também manufatureira, náo ao modelo inglês, alvo inatingível pela modernização mercantilista, mas segundo o sistema colbertiano. A nação seria reorganizada, com um absolutismo que não se constrangia de admitir o despotismo, favorecendo os setores " privilegiados, como a nobreza e o clero, o ensino superior e tudo o que possa haver um raio de confidência" (A. Luís Bessa. Sebastiāo José. Lisboa, 1981, p.167). Sobre esta pedra, que mal durou o tempo de um reinado, formou-se a base, nunca abalada, de todas as modernizações brasileiras.

A modernização, no Brasil, encontra, na sua primeira versão histórica, a modernidade em maturação. As inovações de $\mathrm{D}$. João recaíram sobre um país em transformação, dirigindo-o, e, ao mesmo tempo, freando-o e renovando-o com o transplante da corte portuguesa no Rio de Janeiro. O espírito pombalino permeou a obra da Independência, mediante severo controle da ascensão social que a emancipação política deveria produzir. Entre a sociedade civil, frágil e vigiada, e o estamento aristocrático, deu-se uma transação, alterada em torno dos meados do século XIX. A conciliação política, desarmando os antagonismos, regularia e controlaria a mudança social. Mantida a pirâmide - mantida a "ordem" , como se dizia - o Império escravocrata adia sua mais urgente reforma social, a do cativeiro, logo adiante, para se modernizar. Sem o sonho das manufaturas, arquivado o projeto colbertiano, joga-se na febre das estradas de ferro e dos melhoramentos urbanos. $O$ centro da economia se desloca para as ferrovias, "o maior - dizia o ministro da Fazenda do Governo Provisório - dos instrumentos de civilização e o mais generoso de todos os sistemas de proteção ao trabalho, em todas as suas aplicaçõos nacionais" (Rui Barbosa. Relatório do ministro da Fazenda. Obras Completas, v. XVII, t. II, p. 27). Sem as garantias de juros e a proteção estatal não haveria a estrada de ferro. A agricultura, devastada pelos financiadores de escravos e safras, mal deixava recursos para edificar algumas cidades brasileiras, cuja infra-estrutura dependeu, para se 
fazer, também do capital importado.

Num conto de 1884, Machado de Assis faz a caricatura do ciclo ferroviário, tocando em suas três notas. Em primeiro lugar, a estrada de ferro é o progresso: "o Brasil está engatinhando, só andará com estradas de ferro". Depois, a estrada de ferro é a própria indústria. Em terceiro lugar: o País deve dedicar-se "exclusivamente - notai que digo exclusivamente, diz o personagem, enfaticamente - aos melhoramentos materiais" . O advérbio exclui a questão servil e o debate institucional.

As estradas de ferro não trouxeram o progresso, nem o País começou a andar. Os "proventos da escravidão" (Joaquim Nabuco. $O$ abo. licionismo. São Paulo, 1949, p. 130) mal conseguiram uma superficial modernização pré-industrial e mercantilista. Como todas as modernizaçóes, esta deixou os seus espectros. Compare-se o que restou da prosperidade do café, entre 1860 e 1900, servido por estradas de ferro: os campos calcinados e as cidades-fantasmas? Falhara a dedicação, exclusiva aos melhoramentos materiais, da sátira. A mudança se daria, pensava-se, com o retorno do espírito de Pombal, reerguendo a tocha da ciência. No último quartel do século passado, exaurida a euforia da conciliação, em política, e do ecletismo, em filosofia, revoou sobre o País " um bando de idéias novas... de todos os pontos do horizonte... Positivismo, evolucionismo, darwinismo, crítica religiosa, naturalismo, cientismo em poesia e no romance... transformação da intuição do direito e da política..." (Sílvio Romero. Vários escritos de Tobias Barreto. Ed. Estado de Sergipe, 1926, pp. 23 e 24). As correntes de pensamento diziam que havia um mundo renovado, que era preciso rearticular ao País cadaveroso. $O$ veículo para a renovação era a ciência - a ciência em filosofia, a ciência em poesia, a ciência na literatura, a ciência na política. Era a ciência como salvaç o, retomando-se, nas elites que a promoviam, os elos visíveis das reformas pombalinas (Antônio Paim. História das idéias filosóficas no Brasil. Rio de Janeiro, $3^{\text {a }}$ ed., 1984; Jeovah Motta. Formação do oficial do Exército. Rio, 1976). Todas as idéias postas em circulação acentuavam que a " ciência era o valor mais alto da cultura humana, capaz de resolver todos os problemas" (Evaristo de Moraes Filho. Medo utopia. Rio, 1985 , p. 67). O desenvolvimento do País se daria, portanto, pela via da ciência, cultivada nas academias militares, na Escola Politécnica e nas faculdades de Medicina. Comte recupera Pombal, num Iluminismo, como o do déspota português, tolhido e politicamente condicionado.

Agora o desenvolvimento se implantaria, com o milagre da indus- 
trialização rápida; promovido por um poder espiritual de cientistas. A elite dissidente - dissidente, mas nem tanto, como observamos - forma uma comunidade cujo centro se comporá de militares. Uma circunstância definirá esta liderança. O País se engajara numa guerra continental, que, a julgar pelos precedentes, prometia não ser mais que uma excursão nas fronteiras do Sul. A penosa e angustiada vitória, depois de quatro anos inglórios, mostrara a fraqueza e o atraso do País. Se o País era atrazado, cumpria formar, sobre o retardatário, um país diferente, para outras guerras. Esta visão do País com relação a outro é uma visão pombalina, o criador, em língua portuguesa, do Exército permanente. A tarefa se definia, quer pela ideologia, quer pelos fatos históricos - em lugar de tarefa pode-se falar em missão - para instituir o progresso no trópico, além dos limites do comercialismo, que gerara o Império exportador e importador. Sob a vigilância de uma repuiblica ditatorial (ditatorial a república por inspiração comtiana e também porque, para tamanha obra, se exigia, como veio a se entender ainda um século mais tarde, e é sempre congenial às modernizaçóes, a coação e a repressão), sob a vigilância de uma repuiblica ditatorial, criar-se-ia, fomentar-se-ia, estimular-se-ia uma classe de empresários, sempre tutelados. Uma classe dentro de um estamento. A elite divergente, em oposição à pedantocracia legista, que representava o atraso dos tempos pré-científicos, ditos metafísicos, forma um grupo dirigente, que, apesar da sua coesáo, nunca conseguiu ser dominante, nem se transformar numa classe governante. Seu programa e sua ideologia, ainda que filtrada por meio do Liberalismo, viria a ter uma presença permanente na história brasileira, entroncando-se à base pombalina. Esta talvez seja uma das chaves da história brasileira, ainda não suficientemente identificada e iluminada.

O Positivismo, cujo cerne era a ciência como missão, rescende a Saint-Simon, traindo o mestre de Comte e o próprio Comte inicial, num retorno às origens, germe da futura tecnocracia. Pode-se conjecturar que tal Positivismo estaria infiltrado com a ideologia industrial que predominava na França de Napoleão III, mas sem condescender, se não longinquamente, com as idéias socialistas do mestre (V. Gerschenkron, obr. cit., pp. 23 e 24).

Com a homenagem verbal à ideologia liberal, debaixo de constituições de papel, além da grande modernização de 89-90, na verdade uma gigantesca bolha industrializante, sucedem-se, no espaço de menos de 50 anos, muitas outras. $O$ progresso era tudo, os direitos do cidadáo náo existiam, inclinando, tais empresas, as classes altas para o evolucionismo de Spencer, apto a abrigar as teorias racistas, que, ao justificaremnas, davam-lhe uma base biológica. Para citar exemplos: houve a mo- 
dernização médica, com a vacina obrigatória, uma obra que bem poderia ser feita por um personagem de Ibsen, a modernização urbanística, no Rio de Janeiro, que expulsou moradores e proprietários pobres de suas casas sem que se lhes permitisse o acesso ao juiz. Só faltou, para se caracterizar uma modernizaçáo, a tesoura de Pedro, o Grande, cortando, em pessoa, a barba de seus boiardos, ocidentalizando-os com um toque

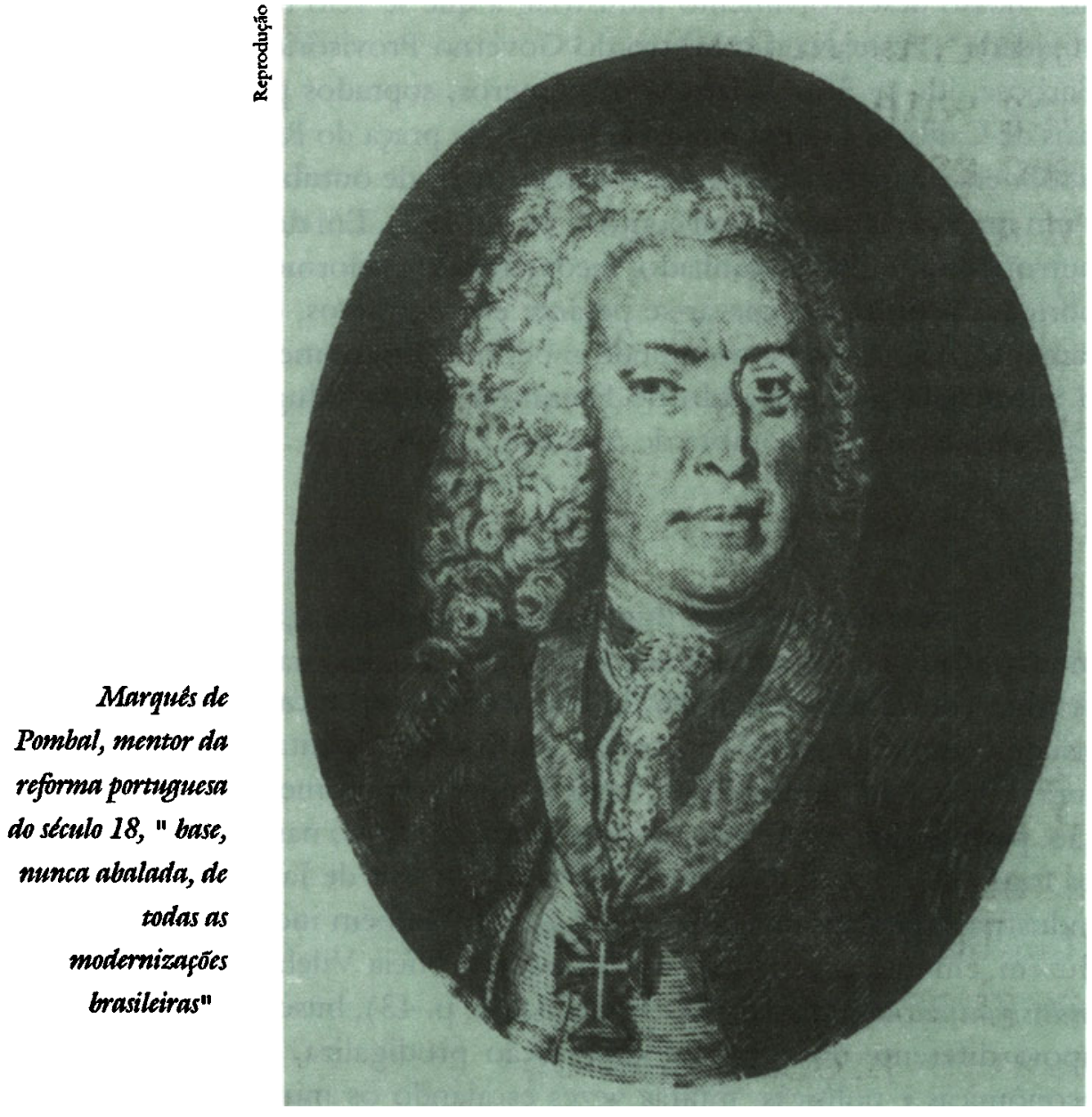

de magia barbeiril (Quanto às modernizaçōes, exemplificativamente: Afonso Arinos de Mello Franco. Rodrigues Alves. v. I, Rio de Janeiro, 1972; José Maria dos Santos. A política geral do Brasil. São Paulo, 1930; José Carlos Sebe Meihey, Cláudio Bertolli Filho. História social da saride: opiniāo pública versus poder. A campanba da vacina de 1904. Estudos Cedhal 5, São Paulo, 1990; Nicolau Sevcenko. Literatura como missão. Sáo Paulo, 1983). O processo faz pensar na "acomodaçáo entre ele- 
mentos hostis", como estāo na modernizaçāo (José Martí. Páginas escogidas. Coleção Austral, pp. 121 e 122). O povo, por esse meio, não participava da mudança: ele a padecia. Foi o que quis dizer Euclides da Cunha, ao notar que estávamos "condenados à civilização" (Os sertôes. Brasiliense, 1985, p. 144).

De que dependia a industrialização, se perguntavam os modernizadores? Ela depende, táo só, de um foco acelerador, difusor e propulsor do " nosso desenvolvimento industrial, a que se veio imprimir inaudita atividade", festejava o ministro do Governo Provisório, em 1890 (Rui Barbosa, id., p. 53). Leiam-se os números, soprados por Próspero, no país de Caliban: O movimento industrial da praça do Rio de Janeiro, em 1888, era de quatrocentos mil contos, em 20 de outubro de 90 chegava a um milhão e duzentos mil contos! (id., p. 158). Em dois anos, o Brasil, outrora mesquinho e acanhado, mediocrizado e adormecido pela rotina, obrigava a Europa a curvar-se perante ele: entramos, de golpe, gloriosamente, magicamente no mundo moderno. Em nome do Liberalismo, o industrialismo favorecido de Hamilton ocupa o lugar de Pombal e Colbert, debaixo da sombra de Augusto Comte.

No desenho de pauta dupla - a da modernização que recobre a modernidade -, uma das linhas repele e vê a outra, na ambigüidade da sombra contra a luz. A linha de baixo critica, ri, escarnece, zomba da sisuda e grandiloqüente construçăo do futuro. A pauta que vê a caricatura, a pauta da modernidade, nem sempre comprometida com a tradição, percebe que, realmente, há uma industrialização nascente, oculta sob os fogos de artifício da agitação da praça do Rio de Janeiro. Há não só industriais que lançam açōes na bolsa, mas também industriais que produzem, em luta pela proteção alfandegária (Nícia Vilela Luz. A luta pela industrialização do Brasil. São Paulo, 1961, p. 43), buscando um tipo de apoio diferente do que a modernizaçáo prodigaliza. Contra barreiras econômicas e políticas, muitas vezes escalando os muros sem derrubálos, uma indústria moderna estava em nascimento. Mais tarde, ela se aliará às classes altas, num consórcio entre o burguês, o fazendeiro e o banqueiro (Warren Dean. A industrializafão de São Paulo. Sáo Paulo, 1971 , pp. 84 e segs.). A essa conjunção de classes altas, conciliando-se a uma realidade patrimonialista e burocrática, somou-se a domesticação das classes subalternas no clientelismo. Essa coligaçáo do alto, com o enfeudamento popular, excluiu os menos abastados, classe média e operários, do papel de árbitro das divergências dos grandes. Desta sorte, a sociedade civil, já sufocada pelo projeto modernizador, perdia toda a 
funçáo política, e, por essa via, também a função econômica. Este era, na verdade, o limite da modernidade: mal e apenas permitia a autonomia das classes altas, ao contrário da modernização, que as aprisionava e as dirigia, mas, em comum uma e outra, exclúam do pacto social o povo.

$O$ incentivador da industrialização, o promotor, o acelerador e o difusor, personificado num nome próprio e não num grupo, chama-se Simão Bacamarte, o herói da sátira de Machado de Assis, O alienista. " A ciência é meu emprego único." Em Itaguaí, nos tempos coloniais, logo depois da eclosáo da Revolução Francesa, ele instala uma casa de loucos. No primeiro momento, recolhe na Casa Verde, o nome do estabelecimento na voz popular, os loucos, assim considerados os que todos identificavam como tais. Os seus métodos científicos podem sair, inclusive pelas alusóes, do Cours de Philosophie Positive. Até agora, a loucura era uma ilha perdida no oceano da razáo, de certo momento em diante seria um continente. Por força dessa teoria, compulsoriamente, o alienista recolheu quatro quintos da população atrás dos muros do hospício. Num terceiro momento, a loucura é outra coisa: é normal e exemplar o desequilíbrio, mas é patológico o equilíbrio. O que a sátira diz é que, pela ciência, não é possível identificar o que é modernização do que não é : a modernização de hoje, se o critério para avaliá-la é a ciência, pode ser a contramodernizaçào de amanhá. Diz mais: a ciência, impenetrável ao entendimento do vulgo, retira a este o poder de contestá-la ("Não há", dizia Comte, " liberdade de consciência em astronomia, física ..." Evaristo de Moraes Filho. Comte. São Paulo, 2a ed., 1983, pp. 14 e 15), validando, desta forma, o poder despótico do tecnocrata. Se houvesse tempo, poder-se-ia ainda discutir a descontinuidade da superposição das teorias e doutrinas, implícita ao processo das modernizaçôes, sem que a teoria anterior exija ou suscite a posterior, revezando-se por urgências ideológicas. Examinar-se-ia, também, a descontinuidade das idéias, circunstância que exclui a idéia de progresso, tal como definida desde o século XVIII. O tempo, não sendo contínuo, é cíclico, irracionalizando o desenvolvimento econômico e social, como nos trabalhos de Sísifo.

De outro lado, sempre satiricamente, o espectador não vê o desenvolvimento nos números que deslumbram os homens de negócios, nem na euforia dos governantes. Ele vê, no mundo dos negócios, o jogo: o jogo oficialmente bancado. $O$ cronista de meados do século, diante da febre ferroviária, zombava: " Ao jogo, cidadão, ao jogo! ... Lançai uma estrada de ferro desde São Cristóvão até o Pará; desmontai as cachoeiras de São Francisco...; fundai um banco, dois mais, de hipotecas, tudo o que quiserdes, porque o nome nada tem com a instituição em si" (Victor Viana. O Banco do Brasil. Rio de Janeiro, 1926, p. 362). O ousado 
cronista, ao imaginar uma estrada que partisse de São Cristóvão - a residência do imperador - até ao nada, sugeria, numa imagem, o oficialismo, a especulaçāo, a inanidade da empresa. A mesma nota vibra em outra sátira, esta agora sobre a modernização do fim do século, em $O$ encilhamento, do visconde de Taunay. Queria-se, na voz da caricatura, promover, agora e já, o progresso dentro da ordem, rompendo com a "acautelada morosidade e a paciente procrastinação" da rotina. O País dormia, hipnotizado: era preciso acordá-lo. Malograda a industrialização, a modernização se faria na agricultura, sob a direçáo do dr. Bogóloff, de Lima Barreto. Os porcos seriam do tamanho dos bois, os bois, do tamanho dos elefantes, graças à ciência, prescrita sacralmente pelo grande químico e fisiologista inglês $H$. G. Wells.

\section{7}

O positivismo pombalista produz, neste século, dois frutos tardios: 1937 e 1964. Em ambos os momentos, o estamento militar, em rearticulação, no primeiro tempo, a ponto de aceitar um líder civil, dispondo de sua presença e de sua queda, proclamou-se modernizador, reformador, com o progresso dentro da ordem. Ou com o desenvolvimento sombriamente envolto na segurança nacional. No segundo caso, $\mathrm{em}$ 64, a má performance do País na guerra, de onde saiu sem o previsto prêmio de ingressar no mundo das potências, com lugar marcado no Conselho de Segurança da ONU, engendrou uma sinistra ideologia, cultivada na Escola Superior de Guerra, fundada pelos oficiais decepcionados com a excursão à Itália. Repetia-se a hora da Guerra do Paraguai (1864-69), numa história mais circular do que progressiva. Náo quero dizer que 64 veio da decepção da guerra, nem que a mudança do fim do século passado decorra da Guerra do Paraguai. $O$ que se quer dizer é que o molde político da mudança se deve, em parte maior, ao papel das Forças Armadas dentro do País. Excluído, para efeito de raciocínio, o Exército, a República decerto viria, mas não viria como veio. Já 64 é impensável sem as Forças Armadas no exercício de um extravagante poder político. Em ambos os casos, a modernizaçáo, como tarefa voluntarista, sem as convulsóes de 37 e 64, se adequaria, com toda a certeza, à modernidade, sem a ingênua queima de etapas. Mentalmente abstraído esse fator, pode-se admitir uma febre de modernidade, como o período Juscelino, que náo foi uma modernização. $O$ regime de 37 queria uma rápida industrialização, expandindo, sobre uma industrializaçáo de modernidade e de guerra empréstimos e estímulos oficiais. Náo aderiu, apesar da nota aguda do nacionalismo, à tese dos industriais das trocas desiguais com os países adiantados, o que exigia, para reequilibrar $o$ sistema, a industrialização em larga escala (v. Joseph L. Love. Theorizing 
underdevelopment: Latin America and Romania, 1860-1950. Review Fernand Braudel Center. v. XI, n. 4. 1988). (Também: Karl Loewenstein. Brazil under Vargas. N. York, 1942.) 64, para caracterizá-lo num traço drástico, foi uma industrialização em que os industriais náo tiveram voz no projeto - eles se transformaram, em escala sem precedentes na história nacional, em concessionários dos favores oficiais (Philippe C. Schimitter. Interest conflict and political change in Brazil. Stanford, 1971, p. 364).

Significativo é que as sátiras sempre acentuem, ao caricaturarem os acontecimentos, o advento do dies irae, dies illa - "o dia da cólera, aquele dia" (terrível). Indicam que as modernizações, que se desenvolvem entre saltos, espasmos e surtos, deixam, na cauda, um cortejo de espectros e malogros. Seus êxitos são os êxitos da modernização, que viriam sem esta, ou que esta perturbou. Seus malogros sáo só delas: os campós calcinados do café, as ruínas do Encilhamento, ruína oficial e que foi oficialmente paga, os subprodutos da favelização com a modernização urbana, a militarização política legada por $37, \mathrm{e}, \mathrm{em} 64$, o símbolo maior: o fantasma das usinas atômicas. Mas, se as sátiras registram o dia seguinte, elas não falam de 37 e 64 . Silenciam porque a sátira se detém diante do odioso, desenvolvendo-se para uma catarse conciliatória. Se Chaplin não produzisse a sua sátira de Hitler antes dos campos de concentração e das câmaras de gás, não mais a produziria. Em segundo lugar, desde Platão (As leis, XI, 935) e Aristóteles (Aristotle's theory of poetry and fine arts. N. York, 1951, p. 374), identifica-se a sátira como forma literária que olha em direção ao outro. O ataque é da sua essência, como é a zombaria, o humor (Northrop Frye. Anatomia da crítica. São Paulo, 1967, p. 220). Ora, nem em 37 nem em 64, a dualidade era a visáo dupla, desvendável pela subtileza do satirista. Havia, com uma intensidade nunca vista antes, a pauta dupla, mas a pontaria em direção ao outro era um ataque sem humor, insuscetível de zombaria. Entre uma pauta e outra não era possível a conciliaçáo, num desfecho de catarse liberadora. Ao contrário, a dualidade continuaria, mesmo nas anedotas e nas lenientes caricaturas da imprensa do ditador. Esta é uma reflexão para outro momento: por que a sátira contra D. Pedro II, contra os positivistas, mas não a sátira contra Stalin, contra Hitler (salvo o precoce Chaplin)? A dualidade está presente, mas já não é mais a dualidade solúvel, conciliável, mas a dualidade que, mantendo o ataque, despede-se da graça, do humor, da zombaria e do riso catártico. Houve, desta maneira, uma suspensão do mais convincente gênero literário brasileiro (também em Portugal, notava Eça de Queiroz: Obr. Compl., v. I p. 1410). Mas o problema não é a sátira, mas a dualidade que está debaixo da sátira uma dualidade que persiste ainda que a sátira saia do campo. 
É indispensável, para a compreensão da pauta dupla - que é a própria modernização -, acentuar que entre uma linha e outra, entre a linha da modernização e a linha da modernidade, há uma oposiç o (Hegel. Vorlesung ïber Ästhetik, Subrkamp, 1970, II, pp. 120 e segs.; Esthétique. Trad. S. Jamkélévicht, Flammarion, 1979, v. 2, pp. 251 e segs.) (Gegensatz), que, mais que uma diversidade, năo se funde numa contradição (Widerspruch). A oposição pode, uma vez que não chega à contradição, e daí, à superaçāo (Aufheben), conciliar-se e acomodar-se num quadro sem afirmaçōes e sem negaçóes. A conciliação, portanto, se aproxima do ceticismo, com a indefiniçáo como norma (Hegel. La rellation du scepticisme avec la philosophie. La essence de la critique philosophique. J. Vrin, Paris, 1972). A oposição está depois da diversidade e antes da contradiçáo (Ciencia de la lógica. Trad. Augusta e Rodolfo Mondolfo. Buenos Aires, 1968; Wissenschaft der Logik. v. 6, Werke, Suhrkamp, 1975). Na oposiçáo o oposto é o seu oposto: a diferença entre uma pauta e outra está, portanto, acabada: os elementos estão contrapostos. Porque o oposto é o oposto do seu oposto, há um influxo entre as duas pautas. Por exemplo, a modernização vai até a modernidade possível, deixando de haver oposição quando uma linha é um enclave, como nas invasóes "desruptivas". Igualmente não há oposição quando há entre uma realidade e outra uma extensão ou um prolongamento, como no exemplo mencionado das colônias gregas. Porque há a oposiçáo, há uma diferença qualificada pelo devenir - um movimento condicionado e limitado, mas um movimento -, ela não se confunde com a imitação, à cópia mimética. A oposição, tolhida e freada, se reflete abstratamente no pensamento, sem ser realidade. A dualidade é vista como um impedimento à atividade humana e como um obstáculo ao real desenvolvimento, a um desenvolvimento que seja mais do que um passo sobre outro passo. Expliquemos.

Na duplicidade, no desacordo, na separaçáo (Zwiespalt) das pautas, uma linha, a da modernização, acumula, soma, progride (Fortgehen, Fotrgang), enquanto a outra, a da modernidade, atualiza, aperfeiçoa, desenvolve (Entwicklung - são termos hegelianos, mas a terminologia não é, neste particular, uniforme). O movimento, no último caso, se de modernidade se trata, não é um reflexo, nem meramente uma transiçáo, mas um processo que náo depende de comandos externos para se realizar (mais para a terminologia do que para o conceito: Encyklopädie der Pbilosophischen Wissenschaften. 1, Suhrkamp, 1973, no 161ñ; Logica. Madrid, 1973, $\left.\mathrm{n}^{\circ} \mathrm{CLXI}\right)$. O exemplo hegeliano para o desenvolvimento é a planta: a planta não se desenvolve por uma força externa, mas a partir de 
seu germe, que a contém de modo ideal (neste passo tem sentido o que se diz no prefácio da edição de $O$ capital de 1867: a pista da lei natural do desenvolvimento - a planta, para se desenvolver, se tivesse consciência, perceberia que se desenvolveria de acordo com o germe, jamais contra ele). O conceito e o exemplo mostram que náo é a força externa, uma direção superior, um enxerto, o que desenvolve a planta, que, com o crescimento, apenas muda de forma. Para transpor a idéia hegeliana à nossa hipótese, deve-se dizer que a modernização não vai além da modernidade: além da modernidade só existem os espectros e as ruínas do dies irae. Fora daí só existem convulsóes, espasmos e quedas. O desenvolvimento é uma realização (é a palavra usada na tradução Bourgeois da Enciclopédia: Paris, 1970, 84). A progressão, que a modernização é capaz de fazer, é uma passagem de um para outro, enquanto o desenvolvimento é o aparecimento de algo adequado ou que o ser comporta, que estava na essência do ser. $O$ conceito de desenvolvimento aproxima-se do conceito de energia - a exterioridade da energia (André Léonard. Commentaire littéral de la logique de Hegel. Paris, 1974, pp. 242 e 244). (É verdade que, em outro momento, Hegel usa a palavra Fortschritt para o que seria desenvolvimento: " a história universal é o progresso (Fortschritt) da consciencia da liberdade.)" (Uma outra terminologia para a mesma idéia: processo por necessidade interior seria o desenvolvimento e processo por necessidade exterior corresponderia à progressáo: Jacques D'Hondt. Hegel. Filósofo de la história viviente. B. Aires, 1971: "Um fim exterior não se apresenta senão como um acidente que interrompe ou perturba a realização ativa da finalidade interna, como um acontecimento que não obedece à necessidade interior ao ser ao qual afeta" . p. 238.) O processo por necessidade externa, a progressão, impulsionado por uma vontade tecnocrática não é mais do que um fim subjetivo de um grupo de pessoas, incapaz, por não se irradiar como força interna, de se incorporar à história. Por isso, em certos casos, as modernizaçóes, depois que chegam ao fim, que é quando a elite, como a encarna Simáo Bacamarte, muda de objetivos, parecem nunca ter existido. Elas se circunscrevem ao tempo circular, com uma memória condicionada ao tempo precário, que duram enquanto outra onda se sobrepóe à atual, desfazendo-se ambas. A história que daí resulta será uma crônica de déspotas, de governos, de elites, de castas, de estamentos, nunca a história que realiza, aperfeiçoa e desenvolve. A história, assim fossilizada, é um cemitério de projetos, de ilusóes e de espectros.

Para clareza da exposição, retornemos a um dos pontos de partida: a pista da lei natural do desenvolvimento, com a obediência às fases do desenvolvimento (Naturgesetz ihrer Bewegung - Entwicklung phasen). O som hegeliano, em que pese a lembrada descaída positivista - é 
óbvio. O desenvolvimento não pode ser a matéria de decretos, nem é assim que uma nação aprende de outra. Uma elite não pode, pela compulsāo, pela ideologia, gerar a naçáo. A nação, que quer se modernizar sob o impulso e o controle da classe dirigente, cria uma enfermidade, que a modernidade, quando ela aflorar, extirpa, extirpando os modernizadores. Todos os países que sofreram modernizaçóes - Alemanha, Japão, Itália, da Península Ibérica e do Leste Europeu - expulsaram, para que o desenvolvimento se irradiasse ao povo, a elite, a classe dirigente, a burocracia coletivista. A modernidade emergiu com a ruptura, construindo, sobre a ruína das autocracias, o desenvolvimento, capaz de se sustentar com movimento próprio, eliminando, juntamente com os males antigos, os males modernos. Todos deixaram de ser uma dualidade, uma imobilizada oposição de direçóes, para revelarem sua identidade cultural, num vôo próprio, dentro do universo, libertos da tradição e da contemplação nacional.

Propóe-se agora, depois de muitas modernizaçóes, mais uma modernização, que se supóe legitimada pelas urnas. Trata-se não de uma modernização pombalino-positivista, mas de uma modernização neoliberal, com o rótulo de social-liberalismo. Ela quer ser uma "centroesquerda modernizadora". O projeto se imporia, na confessada retórica do seu principal fautor, trazido nas asas de Mosca e Pareto. O social-liberalismo entraria em circulação como uma ideologia, uma fórmula política, do alto, tal como se pretendeu, pela palavra de Gentile, qualificar o fascismo como fruto do Liberalismo italiano (José Guilherme Merquior. O liberalismo. Rio de Janeiro, 1991, p.142). Seria a atualização, em segunda máo, do social-liberalismo de Mazzini. Mais uma vez uma elite dissidente - dissidente, porém conservadora - pretende, pela via do Estado, anular o Estado. O paradigma parece estar nos tigres asiáticos, que teriam ingressado no mundo, inscrevendo-se na primeira fila, montados no liberalismo, contra o dragáo do Estado. O Estado, diante estarrecedores índices de miséria, se limitaria, na sua administração, a promover e, se houver sobras públicas, a assistir a população. Abdicaria de um programa de distribuiçáo de rendas - entregue à mão invisível - com todas suas implicaçóes econômicas e sociais, por exorbitante aos fins do Estado. O Liberalismo, em toda a parte uma ideologia da sociedade civil, seria aqui uma ideologia do Estado para a sociedade civil, que recebe as diretrizes do tipo de Estado que pode criar. O corte do Estado - o chamado Estado produtor, na verdade o Estado interventor - se daria com o redimensionamento das tarefas públicas. Ele confunde o Estado, que é, em certos momentos, uma burocracia, capaz de tutelar $\mathrm{e}$ 
de arbitrar os interesses sociais, com o funcionalismo. O Estado se tornaria um mero planejador da infra-estrutura, sobre a qual assentariam as obras econômicas que estimulassem o desenvolvimento, voltando as costas ao País, ao País de uma minoria sitiada por uma maioria faminta e pobre. A proposta implodiu, tal o seu irrealismo, antes mesmo de se formular. Os choques econômicos, os planos que se sucedem aos planos, enterrando uns aos outros, assim que malogram, só conseguiram, como fez o Império, como fez o encilhamento, como fizeram 37 e 64 formar os seus ricos, que florescem ao lado dos ricos arcaicos. O País, eletrocutado pelo projeto modernizador, não reagiu: não o aceitou, nem o sacudiu de suas costas, por carência de meios institucionais. Desta vez, os espectros vagam nas ruas, sem emprego, miseráveis, depois de, perdendo tudo, perderem a esperança.

Percorremos, em quase 200 anos de história, modernizações que sepultaram modernizações, planos que substituíram planos, numa obra de Sísifo. Somemos, às penas de Sísifo, filho de Eolo, condenado a subir e descer regularmente e ciclicamente a montanha, o castigo de Tântalo, rei da Frígia, com sede e com fome, com os pés na água, debaixo da árvore que alimenta. Em nenhum desses surtos, mal entrados numa modernizaçáo abortiva, encontramos a pista da lei do desenvolvimento, a que aludíamos no início. Esbarramos com seus desvios patológicos numa empresa de paranóias sucessivas. Todos os movimentos modernizadores visaram formar, construir, modelar a economia, num campo em que, se racional, a economia não se molda, não se constrói, nem se forma com os instrumentos empregados. O que se forma, sob a tutela de uma classe diretora, orientadora, dirigente, não é a racionalidade do paradigma, que não é a dessa classe dirigente, mas de uma economia diversa, centrada numa outra equação econômica (Max Weber. Historia economica general. México, FCE, 1958, p. 282). Esta é a explicação da causa de perecerem, quando em confronto com o mundo, os empreendimentos gerados pela modernização desvinculada da modernidade.

As modernizaçōes, entre nós, procuraram, sem alcançar, a modernidade industrial, que, por serem modernizadoras, não seriam capitalistas. Por sua vez, o industrialismo náo gerou o Liberalismo econômico, porque o Liberalismo econômico não se gera por decisão oficial. Daí náo saiu uma ordem política liberal, perdida na sombra ideológica permeada pela elite. $O$ Liberalismo econômico, ao se implantar, perverteu-se na conquista, irracionalizadora por natureza, dos favores oficiais. O regime político, retoricamente liberal, acolheu-se, repetidamente, ao primeiro susto, mais fictício do que real, debaixo da proteção das baionetas. A recuperação da modernidade, para desvendar-lhe o leito por onde ela 
corre, não se faz do alto, pela revolução passiva, prussianamente ou pela burocracia. O caminho que leva a ela é o mesmo caminho no qual trafega a cidadania: essa via, que só os países modernos, e não modernizadores, percorreram, não tem atalhos. Os atalhos estão cheios de atoleiros de autocracias. Se o relógio da história não tem um curso fatal, ele não se deixa adiantar para que o relojoeiro queira alcançar, ao nascer do Sol, o meio-dia, trapaceando o espectador e trapaceando-se a si próprio.

\title{
Resumo
}

Em vez de buscar a modernidade, o Brasil padece de ímpetos de modernização, através dos quais se tenta queimar etapas no processo de desenvolvimento. Uma nova modernizaçăo sepulta a anterior e nenhuma consegue fazer com que o País encontre o caminho para o desenvolvimento. Impostas por elites pseudodissidentes em favor dos seus interesses, essas modernizações mantêm a maioria da população alijada de benefícios sociais elementares.

\begin{abstract}
Instead of looking for modernity, Brazil suffers with waves of modernization. Through those waves, we try to burn stages in the process of development. A new modernization buries the previous one and it cannot make the contry finds the right way for development. Imposed by pseudodissidents "elits" favorable to their own interests, those modernizations keep the nost part of population distant from the elementary social benefits.
\end{abstract}

Raymundo Fraro é jurista, sociólogo, historiador e cientista polírico. Lançou, em 1958, a primeira edição de Os Donos do Poder, obra que o consagrou como um dos grandes pensadores da realidade brasileira. Em 1975, publicou Machado de Assis: a pirâmide e o trapézio, uma interpretação histórico-sociológica do universo ficcional de Machado de Assis. Colaborador da revista "Isto É", foi o primeiro professor visitante do IEA-USP, durante o segundo semestre de 1986.

Conferência do Mês do IEA feita pelo autor no dia 31 de março de 1992. 